\title{
熊本県御船町の幼稚園・保育園における眼科健診の報告
}

\author{
矢吹 明子・工藤 奈美・吉川 英子 \\ 佐藤真由美・野村代志子
}

のむら眼科医院

\section{Report of Ophthalmological Screening in the Health Check Program of Kindergarten and Nursery School in Mifune-Machi in Kumamoto Prefecture}

\author{
Akiko Yabuki, Nami Kudo, Eiko Yoshikawa \\ Mayumi Sato, Yoshiko Nomura
}

Nomura eye clinic

要 約

私達は、平成 6 年度より当院のある熊本県御船町において幼稚園健診を開始し、平成 8 年度から は保育園も加えて健診を行っている。今回は、平成 6 年度から 9 年度までの 4 年間の健診結果をま とめたので報告する。

対象は、御船町の幼稚園および保育園の園児延べ1213名で、対象年齢は、0から 5 歳児である。 検查は、当院の眼科医1名と視能訓練士 1 名が各施設に出向いて行った。

健診の結果、要精検例は68名 $(5.6 \%)$ 、既通院例は 35 名 $(2.9 \%)$ であった。

その 68 名中 49 名 $(72.1 \%)$ が当院を受診していた。その 49 名の当院での精密検査の結果、37名 （75.5\%）に治療あるいは経過観察が必要と診断された。検出された疾患は、間歇性外斜視 9 名、調 節性内斜視 1 名、上斜筋麻痷 1 名、外斜位 10 名、弱視 4 名、屈折異常 8 名などであった。

この37名のその後の通院状況を調べたところ、通院が中断していた者が 22 名（59.5\%）にも及ん だ。

また、この要治療例37名のうち、三歳児健診前の年齢であった 3 名を除く 34 名の三歳児健診の受 診結果を調查すると、34名中 30 名が保健婦・看護婦による眼科健診を受診していたが、その30名中 29名が異常の指摘を受けていなかった。

眼科医、視能訓練士による幼稚園および保育園の眼科健診は、間歇性外斜視、調節性内斜視、弱 視などを発見でき有用であったといえる。しかし、受診を中断している者が半数以上にも及んでい たことは問題であった。

別冊請求先（干861-3206）熊本県上益城郡御船町辺田見字馬場410-1

のむら眼科医院 矢 吹 明子

Tel. $096-282-3711$

Key words : ophthalmological screening in the health check program of kindergarten and nursery school, strabismus, amblyopia, refractive error, the health check program for 3-year-olds 


\begin{abstract}
We have been taking part in Ophthalmological screening which is a part of the health check program in kindergarten in Mifune - machi, Kumamoto Prefecture since 1994. This screening system has also been carried out in the nursery school since 1996. We reported here results of Ophthalmological screening from 1994 to1997.

1213 children were examined in this report and the age were ranging from zero to five. An Ophthalmologist and an orthoptist visited and examined children in each institution.

The results showed that 68 children $(5.6 \%)$ were required precise eye examination and 35 children $(2.9 \%)$ were referred to the eye hospital for further treatment.

49 of $68(72.1 \%)$ were referred to Nomua eye clinic where the author is working.

$37(75.5 \%)$ of 49 were required regular follow - up or ophthalmological treatment.

9 of 37 were intermittent exotropias, 10 were exophorias, 1 was accommodative esotropia, 1 was superior oblique palsy, 8 were refractive errors and 4 were amblyopias.

However, 22 of these 37 subsequently dropped out of their treatment program in our clinic.

34 of these 37 had the health check program for 3-year-olds, and 30 of 34 were tested by nurses including public health nurses. However, 29 of 30 cases were not indicated abnormalities with their eyes.

The eye screening by Ophthalmologists and Orthoptists in pre- school children were useful. It was highly effective to find the cases of intermittent exotropias, accommodative esotropias and amblyoia and other disease. We found more than half of children who were needed further treatment dropped out and it was a considerable problem.
\end{abstract}

\section{I. 緒 言}

平成 3 年より三歳児健康診查に視力検查が導 入されて以来、早期に不同視弱視や屈折異常弱 視が発見されるようになってきた。しかし、い まだに就学時、あるいは学校健診で発見される 斜視や弱視の症例があることも事実である。

そこで、就学前の早期に小児眼疾患を発見し、 治療を開始する目的で、私達は当院のある熊本 県御船町において、幼稚園および保育園の眼科 健診を平成 6 年度から行っている。御船町は熊
本市に隣接する人口約 1 万 8 千人の町で、幼稚 園 2 施設、保育園 6 施設を有している。

今回はこの健診結果をまとめたので報告する。

\section{II. 対象及び方法}

\section{1. 対象}

対象は、平成6年度から 9 年度の 4 年間に眼科 健診を実施した御船町の幼稚園および保育園の 園児延べ1213名である。平成 6 年度は、幼稚園 2 施設 119 名、 7 年度は、幼稚園 2 施設103名、

表 1 . 対象

\begin{tabular}{|c|c|c|c|c|c|c|c|c|}
\hline \multirow{2}{*}{ 健診年度 } & \multirow{2}{*}{ 施設数 } & \multicolumn{2}{|r|}{ 対 } & \multicolumn{4}{|c|}{ 象 年 龄 } & \multirow[b]{2}{*}{ 計 } \\
\hline & & 0歳児 & 1 & 2 & 3 & 4 & 5 & \\
\hline 平成6年度 & 2 & & & 7 & 13 & 47 & 52 & 119 \\
\hline 平成7年度 & 2 & & & & 20 & 41 & 42 & 103 \\
\hline 平成8年度 & 8 & 22 & 47 & 62 & 94 & 151 & 162 & 538 \\
\hline 平成9年度 & 7 & 18 & 31 & 56 & 96 & 114 & 138 & 453 \\
\hline \multicolumn{2}{|c|}{ 棓 } & 40 & 78 & 125 & 223 & 353 & 394 & 1213 \\
\hline
\end{tabular}


8 年度からは保育園も加元、 8 施設 538 名、 9 年 度は、 7 施設 453 名である（表 1 ）。

2. 方法

健診は、当院の医師 1 名、視能訓練士 1 名が 各幼稚園・保育園に出向いて行った。

検查項目は、(1)角膜反射法による固視検査, (2)検影法による屈折検査 (未散瞳), (3)眼位検 查：遠見、近見におけるcover test、alternate cover test（必要時には、alternate prism cover testも行う), (4)眼球運動検査, (5)立体視検查 : Lang I（2 歳児以上）であった。検影法につい ては、未散曈で $+2.0 \mathrm{D}$ 以上の遠視、 $2.0 \mathrm{D}$ 以上の 乱視、 $2.0 \mathrm{D}$ 以上の不同視、さらに近視はかなり 強いもののみを要精検例とした。この5項目の検 查から、異常がみられた例を要精検例（新たに この健診で異常が発見された例と眼科を受診し たことはあるが現在通院していない例）と既通 院例（当院を含めいずれかの眼科で通院治療中 の例）に分けた。そして、要精検とした者につ
いては、眼科で精密検査を受けるように保母を 通じて家庭に連絡した。

\section{III. 結 果}

\section{1. 健診結果}

要精検例は68名（5.6\%）、既通院例は35名 (2.9\%) であった。

年齢別では、 0 歳児 0 名 $(0.0 \%) 、 1$ 歳览 2 名 $(2.6 \%) 、 2$ 歳児 6 名 $(4.8 \%) 、 3$ 歳児 13 名 $(5.8 \%) 、 4$ 歳児 18 名 $(5.1 \%) 、 5$ 歳児 29 名 (7.4\%) であった。また、既通院例は、0 歳児 0 名 $(0.0 \%) 、 1$ 歳児 1 名 $(1.3 \%) 、 2$ 歳児 5 名 $(4.0 \%) 、 3$ 歳児 7 名 $(3.1 \%) 、 4$ 歳児 12 名 $(3.4 \%) 、 5$ 歳児 10 名 $(2.5 \%)$ であった。 0,1 歳児の要精検率は低率であった（表 $2-a ） 。$

年度別では、平成 6 年度 15 名 $(12.6 \%) 、 7$ 年 度 4 名 (3.9\%)、 8 年度 27 名 $(5.0 \%) 、 9$ 年度 22 名·(4.9\%) であった。また、既通院例は、 6 年

表 $2-\mathrm{a}$. 健診結果《年齢別》

\begin{tabular}{cccl}
\hline & 対象例 & \multicolumn{1}{c}{ 要精検例 } & 既通院例 \\
\hline 0歳児 & 40 & $0(0.0 \%)$ & $0(0.0 \%)$ \\
1歳児 & 78 & $2(2.6)$ & $1(1.3)$ \\
2歳児 & 125 & $6(4.8)$ & $5(4.0)$ \\
3歳児 & 223 & $13(5.8)$ & $7(3.1)$ \\
4歳児 & 353 & $18(5.1)$ & $12(3.4)$ \\
5歳児 & 394 & $29(7.4)$ & $10(2.5)$ \\
\hline 計 & 1213 & $68(5.6)$ & $35(2.9)$ \\
\hline
\end{tabular}

表 $2-b$. 健診結果《年度別》

\begin{tabular}{cccc}
\hline & 対象例 & 要精検例 & 既通院例 \\
\hline 平成6年度 & 119 & $15(12.6 \%)$ & $3(2.5 \%)$ \\
平成7年度 & 103 & $4(3.9)$ & $5(4.9)$ \\
平成8年度 & 538 & $27(5.0)$ & $10(1.9)$ \\
平成9年度 & 453 & $22(4.9)$ & $17(3.8)$ \\
\hline 計 & 1213 & $68(5.6)$ & $35(2.9)$ \\
\hline
\end{tabular}


度 3 名 $(2.5 \%) 、 7$ 年度 5 名 $(4.9 \%) 、 8$ 年度 10 名 $(1.9 \%) 、 9$ 年度 17 名（3.8\%）であった。平 成 6 年度は初回の健診であったため、少しでも 異常が疑わしい例は全て眼科を受診するように 説明したため要精検率は高率になった（表 2 b)。

\section{2. 要精検68名の疾患名について}

68名の中で、眼位異常が39名 $(57.3 \%)$ と最 も多く、その中でも間歇性外斜視 17 名と、外斜 位（15வ以上）10名が多かった。

屈折異常は 19 名（27.9\%）で、その中で乱視 が12名と多くみられた。(表 3 )

その他の眼疾患は 10 名 (14.7\%) で、潜伏眼 振や睫毛内反がみられた。

3 . 要精検 68 名の当院への受診の割合

御船町に眼科は当院のみであるため、当院へ の受診は68名中 49 名 $72.1 \%$ と高率であった。そ こで、当院を受診した 49 名の精密検査の結果に ついて検討した。

4. 当院を受診した49名の精密検査の結果

精密検査の結果を、要治療・要再検・治療不 要・異常なしの4つに分類した。

要治療は37名 $(75.5 \%) 、$ 要再検は 2 名 $(4.1 \%) 、$ 治療不要は 6 名 $(12.2 \%)$ 、異常なしは 4 名 (8.2\%) であった。(表 4)

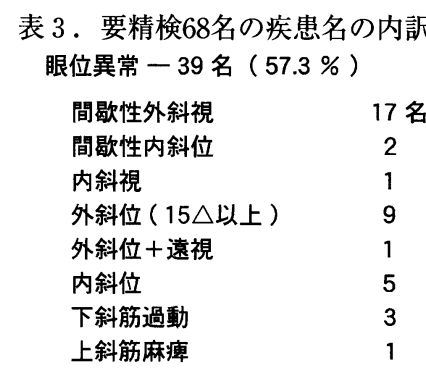

屈折異常 - 19 名（27.9\%）

$\begin{array}{lc}\text { 乱視 } & 12 \text { 名 } \\ \text { 近視 } & 1 \\ \text { 不同視 } & 6 \\ \text { その他 - 10名 ( } 14.7 \%) & \\ \text { 潜伏眼振 } & 1 \text { 名 } \\ \text { 斜頸・瞳孔不同 } & 1 \\ \text { 盖明・流淚 } & 1 \\ \text { 睫毛内反 } & 2 \\ \text { Lang I (-) } & 3 \\ \text { 片眼固視不良+遠視 } & 1 \\ \quad \text { 片眼固視不良+Lang I (-) } & 1\end{array}$

ここで、要治療とは、眼鏡処方、弱視訓練、 斜視訓練、斜視手術 といった眼科的治療の必要 な例と、定期的に検查をして経過観察をする必 要のある例である。要再検は、一度のみの検査 では異常の有無の判定ができなかった例である。 治療不要は、軽度の屈折異常、軽度の斜位はあ るけれども定期的検查、治療を必要としない例 である。

要治療37名の診断名は、間歇性外斜視 9 名、 調節性内斜視 1 名、外斜位 10 名、内斜位 1 名、 上斜筋麻瘏 1 名、下斜筋過動 2 名、不同視弱視 3 名、潜伏眼振を伴う屈折異常弱視 1 名、屈折 異常 8 名、睫毛内反 1 名であった。（表 5 ）

このうち、屈折異常 8 名15眼の屈折異常の種 類は、混合乱視 10 眼、遠視性乱視 3 眼、近視性 乱視 2 眼 であった。

要治療37名の中で、 2 名は家族が眼位異常に 気付き他院を一度受診したけれども、その後は 放置されていた。

また、 3 歳児健診で屈折異常、視力不良の指摘

表 4 . 当院受診者 49 名の精密検査の結果

$\begin{array}{lcc}\text { 要治療 } & 37 \text { 名 } & (75.5 \%) \\ \text { 要再検 } & 2 & (4.1) \\ \text { 治療不要 } & 6 & (12.2) \\ \text { 異常なし } & 4 & (8.2)\end{array}$

表 5 ．当院に扔ける精密検査結果（診断名）

\begin{tabular}{l|c|c}
\hline & 要治療 & 要再検 \\
\hline 間歇性外斜視 & 9 & \\
調節性内斜視 & 1 & \\
外斜位 & 10 & \\
内斜位 & 1 & \\
上斜筋麻㾇 & 1 & \\
下斜筋過動 & 2 & \\
不同視弱視 & 3 & \\
屈折異常弱視 & 1 & \\
屈折異常 & 8 & \\
睫毛内反 & 1 & \\
斜視疑い & & 2 \\
\hline \multicolumn{1}{c|}{ 計 } & 37 名 & 2 名 \\
\hline
\end{tabular}


を受けていたが、眼科を受診していなかった者 が1名、通院していなかった者が 2 名みられた。

要再検としたのは、2名とも斜視疑いであっ た。

5. 要治療37名の現在の通院状況

要治療37名のうち、通院が継続できている例 は12名 $(32.4 \%)$ 、通院の中断している例は 22 名 (59.5\%)、治療が終了している例は 3 名（8.1\%） であった。

弱視は全例通院継続していたが、間歇性外斜 視では 9 名中 4 名が中断していた。中断例で、 多かった疾患は外斜位 10 名中 9 名と、屈折異常 8 名中 6 名であった。(表 6 )

中断時期について調査してみると、 1 2 度 の受診後の中断例が18名と最も多く、中断例の $75 \%$ を占めていた。屈折異常の 2 名は、眼鏡処 方直後より中断し、間歇性外斜視の 1 名も膜プ リズム処方直後より中断していた。（表 7 ）

6. 要治療例の三歳览健診の受診結果（表 8 ）

表 6 . 要治療 37 名の現在の通院状況

\begin{tabular}{|c|c|c|c|}
\hline & \multicolumn{3}{|c|}{ 通院 状 況 } \\
\hline & 継続 & 中断 & 終了 \\
\hline 間歇性外斜視 & 5 & 4 & \\
\hline 調節性内斜視 & 1 & & \\
\hline 外斜位 & 1 & 9 & \\
\hline 内斜位 & & 1 & \\
\hline 下斜筋過動 & & 2 & \\
\hline 上斜筋麻㾝 & & & 1 \\
\hline 不同視弱視 & 3 & & \\
\hline 屈折異常弱視 & 1 & & \\
\hline 屈折異常 & 1 & 6 & 1 \\
\hline 睷毛内反 & & & 1 \\
\hline $\begin{array}{c}\text { 計 } \\
(\%)\end{array}$ & $\begin{array}{c}12 \\
(32.4)\end{array}$ & $\begin{array}{c}22 \\
(59.5)\end{array}$ & $\begin{array}{c}3 \\
(8.1)\end{array}$ \\
\hline
\end{tabular}

要治療37名のうち、三歳児健診前の年齢であ った 3 名を除く 34 名について、三歳児健診の結 果を検討した。34名中31名が三歳児眼科健診で は異常の指摘を受けていなかった。

御船町の三歳児健診は、平成 8 年度までは保 健婦・看護婦により、問診と視力検査中心に行 われており、 8 年度途中からは眼科医が参加し、 健診受診者全員に対して屈折・眼位検査も行う ようになった。そこで、この二つの時期に分け て検討した。

看護婦・保健婦による健診の受診者は30名で、 異常の指摘を受けていなかった者が、30名中29 名にも及んでいた。

三歳児健診で異常の指摘はあったものの通院 できていなかったり、眼科を受診していなかっ た例も 3 名あった。その 3 名の当院での診断名 は、屈折異常弱視 1 名、遠視性乱視 1 名、内斜 位を伴う遠視性乱視 1 名であった。

表 7. 通院を中断した22名の中断時期 眼鏡処方後 2 名（屈折異常

膜プリズム処方後 斜視訓練終了後 経過観察中（1～2度受診後） 18 （間歇性外斜視 1 ) （外斜位 (間歇性外斜視 3 ) (外斜位 8 ) (内斜位 1 ) (下斜筋過動 2 ) (屈折異常 4 )

表 8. 要治療例の三歳児健診の受診結果（三歳児健 診前の年踚であった 3 名を除く 34 名)

\begin{tabular}{|c|c|c|c|}
\hline & $\begin{array}{l}\text { 平成3 8年度健診 } \\
\text { 保健婦 看護婦 }\end{array}$ & $\begin{array}{l}\text { 平成8 9年度健診 } \\
\text { 眼科医 保健婦 }\end{array}$ & 計 \\
\hline 指摘なし & 29 & 2 & 31 \\
\hline 指摘あり & 1 & 2 & 3 \\
\hline 計 & 30 & 4 & 34 \\
\hline
\end{tabular}




\section{IV. 考按}

三歳児健診に眼科検査が導入されて以来、多 くの斜視や弱視が発見されるようになった。し かし、三歳児健診以降、就学児健診以前の健診 は、実際には行われているのかもしれないがそ の報告は少ない。我々の調べた限りでは、古く は原田ら ${ }^{1)}$ 稲富ら ${ }^{2)}$ の報告、最近のものとして

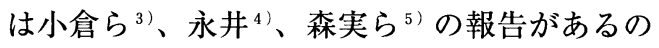
みである。それぞれ、健診の方法は多少異なる が、要精検率は2.0〜 $5.8 \%$ \%あり、我々の健診 の5.6\%とほほ同様であった。

我々の健診で発見された疾患としては、眼位 異常が多く、特に間歇性外斜視と外斜位（15 以上）が多かった。ここで、外斜位を要精検と するかどうかは異論のあるところと思われるが、 検査の際には、幾分緊張しており外斜視が出に くいのではないかと考え、我々は眼科受診をす すめている。実際に、健診時に外斜位と診断さ れ、当院の検査で間歇性外斜視と診断した者が 1 名見られた。

しかし、当院を受診し、要治療と診断した間 歇性外斜視の 9 名中 4 名と、外斜位 10 名中 9 名が 途中で通院を中断している。これらの疾患では、 受診後直ちに治療を開始するのではなく、現在 のところあまり問題はないと説明しているため に親も安心して来院しなくなるのではないかと 思われる。もちろん、普段外斜位であれば両眼 視機能の発達にも大きな影響はないと考えられ る。しかし、斜視角が大きい場合は今後、斜位 が斜視に移行することがないかどうか経過を追 う必要があると思われる。

他の眼位異常としては、少数ではあるが調節 性内斜視、上斜筋麻瘏も発見できた。上斜筋麻 痺例は斜頸のため首の筋肉の手術を受けていた が、斜頸は改善されていなかった。家族の者は、 今回の健診の指摘により初めて眼性斜頸という ものを知ったとのことであった。

また、弱視については、不同視弱視 3 例、屈 折異常弱視 1 例を検出できた。これは、全体の 0.33\%である。要精検とした者がすべて当院を 受診しているわけではないので、正確な比較は できないが、小倉ら ${ }^{3)}$ の $0.6 \%$ 、永井 ${ }^{4)}$ の $1.01 \%$
という報告より低率となった。

また、屈折異常は 12 名（弱視 4 名を含む）で 全体の $0.99 \%$ であり、これは他の報告 2) 3) 6) と 比べ、かなり低率である。さらに、屈折異常例 の中で最も多かったのが混合乱視であり、遠視 例は不同視弱視の1名を含め 2 名のみであった。 遠視に関して、小倉ら ${ }^{3)}$ は3.3\%、神田ら ${ }^{6)}$ は $2.1 \%$ 、と報告している。我々の健診の屈折検査 は未散瞳のため、屈折值が幾分近視側へ寄って いるものと思われるが、本当に遠視の見落とし がないかどうか今後の健診で検討したいと考え ている。

次に、通院中断例であるが、要治療とした 37 名中 22 名（59.5\%）が途中で通院を中断してい た。これについては、神田 ${ }^{6)} 、$ 黒田 ${ }^{7)}$ が三歳児 健診後の通院状況について報告しているが、こ れらの報告でも約4割が中断するとしている。健 診でせっかく異常を発見しても、その後中断し てしまう者が多いことは残念なことである。こ れについて、神田 ${ }^{6)}$ は健診で発見される例の家 族は治療に対する熱意が少ないためと述べてお り、黒田 ${ }^{7}$ は病状の理解ができないため勝手な 解釈で放置する例があることと、治療に対する 不安があることと述べている。我々の場合、通 院が絶対必要と思われる調節性内斜視、弱視例 は全例通院継続していた。これらの疾患は視力、 眼位などの異常をはっきり示すことができるの で親も理解しやすかったものと思われた。

一方、通院中断例は間歇性外斜視、外斜位、 下斜筋過動、屈折異常の例が多かった。中断時 期は屈折異常の 2 名が眼鏡処方後、間歇性外斜 視の 1 名が膜プリズム処方後であった。このこ とは、小さな子供に眼鏡をかけさせたくないと いう親の抵抗のあらわれと思われる。また、経 過観察とした間歇性外斜視、外斜位、内斜位、 下斜筋過動、屈折異常については、1〜2回の 受診の後来院しなくなっている。これは、外見 上あまり目立つことがなく視力も良好であり、 親の認識が薄く危機感が少ないためと思われる。

次に、我々の健診と三歳児健診との関連を探 ってみた。

今回の健診で異常ありとした者で、三歳児健 診で異常を指摘されていなかった者が34名中31 
名みられ、眼科医が参加していない場合は30名 中29名にも及んでいた。このことは、三歳児健 診に眼科検查が取り入れられたといっても眼科 スタッフが参加していない場合は見落とされる 場合があることを示しており、三歳児健診に眼 科スタッフが是非参加する必要があることを示 唆するものである。

また、御船町の場合、平成 8 年度から眼科医 が三歳児健診に参加しているが、同地区の三歳 児健診の受診率は約 $80 \%$ ありり、未受診者 $20 \%$ の中に眼疾患のある者がいる可能性もある。ま た、一度指摘を受けても眼科を受診していない 例もみられる。このような例でも二度、三度同 じ指摘を受けると、眼科を受診するようである。 さらに、 $4 \sim 5$ 歳児では 3 歳児より検査にも協 力的で、異常の検出率も高くなると思われる。 そのような点から、三歳児健診に眼科検查が導 入された現在でも幼稚園・保育園において眼科 健診を行うことは意義のあることであると考え ている。

関谷ら ${ }^{8)}$ も視力発達の感受性期間にできるだ け多くの回数の眼科健診を行うことは大切であ ると述べている。そしてさらに、乳幼览期に眼 科健診を毎年行い、健診の機会を増やすことで、 家族、保母といった幼児の周りの人達の、小児 眼疾患に関する意識も高めることができるので はないかと考えている。

\section{文献}

1) 原田政美, 山本裕子：就学前児童の斜視及び 弱視集団検診，眼臨．55．374-377．1961.

2 ）稲富 誠 他：保育園・幼稚園における眼検 診，眼臨. 70. 95-99. 1976

3 ）小倉洋子, 久保田伸枝 他: 視能訓練士の参 加した 4 歳 6 力月児健診の成績, 眼臨. 84 .
337-340, 1990.

4）永井イヨ子：神奈川県域の 4 5 歳児集団検 診 18年間の集計〜，眼臨. 84. 341-347, 1990.

5 ）森実秀子 他：町田市で試行した幼児の眼科 検診について，日本の眼科．58．383-389. 1987.

6 ）神田孝子：3 歳児健康診查における眼科検診, 眼臨. 84. 69-75. 1990.

7 ）黒田紀子：三歳児眼科健診の意義と現状，日 本の眼科. 68. $109-114.1997$.

8 ）関谷善文：第14回日本弱視斜視学会講習会 「テーマ乳幼児健診〜これからの三歳児健診 ， 上本弱視斜視学会報．35（3)．512. 1998 .

1. 要精検者のうち、親が気づいていたのはどれ くらいでしたか?

2. 治療中断例がかなり多いようですが、それに ついてはどうお考えですか?

\section{答弁}

1. 当院で把握できた要治療例37名について答え させて頂きます。要治療37名中、親が異常に 気づいていたのは、8名21.6\%でした。

2 . 健診で発見される例は、自覚症状もなく、周 囲の者が異常に気づきにくいために、親の疾 患に対する認識がとても少ないことと、治療 に対する抵抗があるのではないかと考えてい ます。今後の対策として、健診時に指摘した 眼疾患の説明書を親に配布することと、当院 受診時に治療の必要性を時間をかけて充分に 説明することを考えています。 